\title{
Antibacterial Activities of Some Medicated Soaps on Selected Human Pathogens
}

\author{
OBI. C. N. ${ }^{*}$ \\ Department of Microbiology, College Of Natural Sciences, Michael Okpara University of Agriculture, Umudike, P. M. B. 7267, \\ Umuahia, Abia State, Nigeria \\ *Corresponding author: b4brocliff@gmail.com
}

Received October 14, 2014; Revised October 29, 2014; Accepted November 04, 2014

\begin{abstract}
Twelve medicated soaps: Crusader, Septol, Carat, 14 days, Funbact, Lifebouy, Safeguard, Tetmosol, TCP, Dettol, Delta and Antigal were investigated for their antibacterial activities against Staphylococcus aureus and Escherichia coli. Two cloth washing soaps (Key and Truck) were used as control. Identification of the bacterial species was by standard microbiological techniques which included colonial examination, Gram staining and biochemical testing. Minimum inhibitory and minimum bactericidal activities of the soaps were determined by discagar diffusion method. Profloxacin was employed as a positive control antibiotic. Crusader soap had the highest antibacterial activity (25 mm, against Staphylococcus aureus) while Antigal exhibited the least zone of inhibition (9 $\mathrm{mm}$ against Staphylococcus aureus). Significant differences $(\mathrm{P}<0.05)$ were observed on the different concentrations of soap preparations used in the work. Staphylococcus aureus was very sensitive to most of the antibacterial soaps used, while Escherichia coli showed higher resistance to the soaps. The medicated soaps analysed have bacteriostatic and bacteriocidal effects on the test pathogens while complete resistance was shown by some of the test isolates even at higher concentrations of the soap preparations used. The cloth washing soaps had no antibacterial effect on the tested pathogens. The use of medicated soaps is thus recommended in homes, schools, offices and hospitals as a way of minimizing or stopping infections that are hitherto spread through the hands.
\end{abstract}

Keywords: bacteria, infections, medicated soaps, resistance, sensitivity

Cite This Article: OBI. C. N., "Antibacterial Activities of Some Medicated Soaps on Selected Human Pathogens.” American Journal of Microbiological Research, vol. 2, no. 6 (2014): 178-181. doi: 10.12691/ajmr-2-6-3.

\section{Introduction}

Soaps and other cleansing agents have been around for quite a long time. For generations, hand washing with soap and water has been considered a measure of personal hygiene. Bacteria are very diverse and present in soil, water, sewage and on human body and are of great importance with reference to health (Johnson et al., 2002). In 1961 the U.S public Health service recommendation directed that personnel wash their hands with soap and water for 1 to 2 minutes before and after client contact. The antibacterial soaps can remove 65 to $85 \%$ bacteria from human skin (Osborne and Grube, 1982). Although fats and oils are general ingredients of soaps but some detergent additives enhance the antibacterial activities of soaps (Friedman and Wolf, 1996).

Transient bacteria are deposited on the skin surface from environmental sources and cause skin infections. Examples of such bacteria are Pseudomonas aeruginosa (Fluit et al., 2001) and Staphylococcus aureus (Higaki et al., 2000). The importance of hand washing is more crucial when it is associated to health care workers because of possible cross contaminating of bacteria that may be pathogenic or opportunistic (Richards et al., 1999). Hand hygiene and prevention of infection through the use of medicated soaps has been well recognized. A large number of chemical compounds have the ability to inhibit the growth and metabolism of microorganisms or kill them. The number of chemicals is enormous, probably at least 10, 000 with 1,000 commonly used in the hospital and homes. Chemicals exist as solids, liquids and gases. Of the many groups of chemicals used to reduce or destroy microbes important groups include hydrogen, phenols, soaps, detergents, ammonia compounds, alcohols, heavy metals, acids and certain special compound. Disinfection, decontamination, antisepsis/sanitization and sterilization, just naming a few are terms that describe the process of cleaning by either soaps/detergents or other cleaning agents. Numerous cleaning agents are available in the market, which are presented in various forms with distinct formulation. Triclosan, trichlorocarbanilide and Pchloro-in-xylenol (PCMX/Chloroxylenol) are the commonly used anti-bacterials in medicated soaps. These are generally only contained at preservation level unless the product is clearly marked as antibacterial, antiseptic, or germicidal (Larson et al., 1989).

Scrubbing body or hands, particularly with soaps is the first of defense against bacteria and other pathogens that can cause colds the Flu, skin infection and even deadly communicable diseases (Kimel, 1996). Conceptually, many people consider that an antimicrobial portion of soaps is effective at preventing communicable disease. 
But now researchers highlight that too much of it can have the opposite effect spreading disease/infection instead of preventing them (Poole, 2002). Over-utilization of medicated rendering might result in antimicrobial resistance and even rendering an individual more vulnerable to microbial attacks such as opportunistic skin infections (White and McDermolt, 2001). Unfortunately, in the long run may affect the consumers, because overuse of these agents can ascribe to the emergence of drug, resistant micro organisms. This research work carried out in 2004 was aimed at determining the antibacterial activities of some commonly used medicated soaps in selected human pathogens.

\section{Materials and Methods}

\subsection{Sample Collection}

The medicated and toilet soap samples used for the study were purchased from standard cosmetics and pharmacy stores in Umuahia, Abia State. The batch numbers, expiry dates and the presence or absences of the manufacturers seal were noted

\subsection{Isolation of Microorganisms}

Sterile swab sticks were moistened with sterile peptone water, and were used to collect skin swabs samples from the neck, armpit, chest, face and hand of students of the department of Microbiology, Michael Okpara University of Agriculture, Umudike. The skin areas sampled were first swabbed with methylated spirit to remove the transient micro flora. The samples collected with swab sticks were then used to inoculate already prepared Nutrient and Mcconkey Agar (Biotech, England) plates. The cultured plates were then incubated at $37^{\circ} \mathrm{C}$ for 48 hours. Biochemical characterization and identification of the test pathogens were carried out using standard identification manual (Cheesbrough, 2005).

\subsection{Preparation of Soap Samples}

A sterile blade was used to scrap one gram (1 g) each of the soaps and which quantity was dissolved in $9 \mathrm{mls}$ of sterile distilled water to a give a stock solution of $10^{-1}$. These stock solutions were then stored in a refrigerator in well sealed containers for future use.

\subsection{Preparation of Disks with Soap Samples}

Disks of diameter $6 \mathrm{~mm}$ were bored using disc borer. The discs were then wrapped in foil paper and sterilized in a hot air oven at $100^{\circ} \mathrm{C}$ for 1 hour and were later soaked in the different soap solutions for a period of one hour to ensure full saturation of the soap preparations. The discs were then aseptically removed from soap solution and allowed to dry in an oven at $25^{\circ} \mathrm{C}$. They were then packed into sterile bottles, corked and stored in the refrigerator for future use in susceptibility test (Selvamohan and Sandhya, 2012).

\subsection{Antimicrobial Susceptibility Testing}

\subsubsection{Disk Agar Diffusion Method}

The disk agar diffusion method as originally described by Bauer et al., (1966) was used. Mueller- Hinton agar plates were prepared for the isolates. Plates were dried with their lids ajar (slightly raised) at a temperature of $60^{\circ} \mathrm{C}$ in the oven for 15 minutes. The test organisms from growth on nutrient agar plates incubated at $37^{\circ} \mathrm{C}$ were suspended in saline solution $(0.85 \% \mathrm{Nacl})$ and adjusted to match a turbidity of 0.5 McFarland Standard. The standardized suspension was used to inoculate the surfaces of Mueller Hinton agar plates using sterile cotton swab. Different concentrations of the various soap samples in the range of $500 \mathrm{mg} / \mathrm{ml}$ to $62.5 \mathrm{mg} / \mathrm{ml}$ were prepared (using sterile distilled water) following serial dilution (Ndukwue et al., 2005). The plates were left for about 30 minutes; the disks were aseptically transferred directly into the sensitivity plates with the aid of a sterile forceps. Within 30 minutes of application, plates were inverted, incubated at $35^{\circ} \mathrm{C}$ for 24 hrs and then were examined for of zone of inhibition around the disk (Selvamohan and Sandhya, 2012)

\subsection{Minimal Inhibitory Concentration and Minimal Bactericidal Concentration Test}

The dilution susceptibility test was used to determine the MIC and MBC values. A series of Mueller-Hinton broth containing varying concentrations of the various soap samples in the range of $500 \mathrm{mg} / \mathrm{ml}$ to $62.5 \mathrm{mg} / \mathrm{ml}$ was prepared and incubated with a standard density of the test organisms. The lowest concentration of the soap sample resulting in no growth after 18 - 24 hrs of incubation was the MIC. The MBC was ascertained by sub-culturing from the tubes which showed no growth into a fresh medium lacking the varying concentration of soap samples. The lowest soap concentration from which the microorganisms did not grow when transferred to a fresh medium is the MBC.

\subsection{Statistical Analysis}

The data obtained from this study were analyzed statistically using Analysis of Variance (ANOVA).

\section{Result and Discussion}

Results of this investigation revealed that most of the assayed medicated soaps have antibacterial activity, though to varying degrees as indicated by the inhibition of the growth pattern of the isolates. When the efficacy of the antibacterial soap were compared using the disc agar diffusion method, Crusader was found to be most effective against all the bacteria strains tested having the highest zone of inhibition ( $25 \mathrm{~mm}$ ) against Staphylococcus aureus and $20 \mathrm{~mm}$ against Escherichia coli at the highest dilution used. Antigal exhibited the least antibacterial activity with zone of inhibitions of $9 \mathrm{~mm} 5 \mathrm{~mm}$ respectively against $S$. aureus and E. coli respectively. Presently, there is no documented research work on the antibacterial activity of Crusader and Antigal.

The result of the minimum inhibitory showed that Crusader had better MIC and MBC of $62.5 \mathrm{mg} / \mathrm{ml}$ and 125 $\mathrm{mgl} / \mathrm{ml}$ respectively on $S$. aureus. For $E$. coli, the MIC and MBC were $125 \mathrm{mg} / \mathrm{ml}$ and $250 \mathrm{mg} / \mathrm{ml}$ respectively. Antigal had higher MIC of $500 \mathrm{mg} / \mathrm{ml}$ and MBC of 500 
$\mathrm{mg} / \mathrm{ml}$ for $S$. aureus and E. coli than Crusader. This means that this soap is needed in higher concentrations to kill or inhibit the growth of these pathogens as against Crusader soap. Profloxacin (control) had MIC and MBC (13.25 $\mathrm{mg} / \mathrm{ml}$ and $31.25 \mathrm{mg} / \mathrm{ml}$ ) respectively against $S$. aureus and MIC and MBC $(<13.25 \mathrm{mg} / \mathrm{ml}$ and $<31.25 \mathrm{mg} / \mathrm{ml})$ respectively against $E$. coli. These values are lower than that recorded against any of the medicated soaps.

The control soap samples (Key and Truck) had no observable inhibition against the test pathogens. This justifies why people do not use the control soaps as medication in control of pathogens via bacterostatic or bactericidal activities even though they possess saponin effects for which reason they have been employed as trusted washing soaps for decades now

Analysis of variance for the Means of antibacterial activities among the soaps revealed positive correlations $(\mathrm{P}<0.05)$. It was observed that significant differences exist among the different concentrations used for the study with $500 \mathrm{mg} / \mathrm{ml}$ (25 mm) having more zones of inhibition than other concentrations: $250 \mathrm{mg} / \mathrm{ml}$ (21 mm) $125 \mathrm{mg} / \mathrm{ml}$ (18 $\mathrm{mm})$ and $62.5 \mathrm{mg} / \mathrm{ml}(14 \mathrm{~mm})$, for Crusader Soap against $S$. aureus. For the other medicated soaps used in this study, effective inhibition of the test isolates decrease in the order: Crusader (25 mm), Septol (23 mm) Carat (20 mm) 14-days (18 mm), Funbact (16 mm), Safeguard (14 mm), Tetmosol (10 mm), TCP (9 mm), Dettol (6 mm) Delta (6 $\mathrm{mm}$ ) and Antigal (5 mm).

It was clearly seen from this study that Gram positive bacterium ( $S$. aureus) was killed at low concentrations of soaps than Gram negative bacterium (E. coli). This observation according to Rama Bhat et al (2011) may be explained by the fact that triclosan exhibits particular activity against gram positive bacteria (Bhargava and Leonard, 1996) due to differences in the cell wall composition. In a similar work, Nwambete and Lyombe (2001) reported that Dettol, Lifebuoy and Tetmosol had inhibitory activities against $E$. coli and $S$. aureus at lower concentrations than that tested in this work. Lifebuoy and Dettol were also reported to have inhibitory effects against E. coli and S. aureus and also against Pseudomonas aeruginosa (Feroze et al., 2014)

Majority of the assayed medicated soaps have demonstrated satisfactory effect, particularly the antibacterial activity, hence buttressing the information written on the soap labels that they posses antibacterial activity. This is due to differences in the active antibacterial ingredients and type of formulations used (Nwambete and Lyombe, 2011). However, repeated use of the agents might have caused some resistance as noted in the work.

The best in antibacterial activity of all the soaps used is Crusader exhibiting maximum zone of inhibition for the test isolates. This could be attributed to its unique formulation using potassium mercuric iodide. Tetmosol is primarily used for its scabicide effect; however, it exhibited moderate antibacterial activity which is attributed to monosulfiram within its formulation (White house, station, 2008).

The inhibition of the growth pattern of the isolates indicates the varying abilities of the organism to resist the antimicrobial effect of the soaps. However, these variations could be due to differences in the nature and structures of the bacterial cell wall since it is ultimate target of any antimicrobial agent or disinfectant. The active ingredient in the soap is what distinguishes in the antimicrobial agents. The indicated soaps in this study were found to contain trichlocarban and triclosan as active antimicrobial agents. These chemical compounds functions by denaturing cell activity and interfering with microbial metabolism. These depend on a number of factors such as the inherent properties of the organisms, contact time, the composition of the soaps (e.g triclosan) concentration or individual formulation and skin sensitivity

Soaps are intended for reduction of the inoculums sizes of pathogenic and non-pathogenic microorganisms, the later include the normal flora. Of these, two types are well known viz resident that are the normal flora of the skin and other human body parts, and transient flora that are usually picked up from objects or other human beings (White house station, 2008).

Thus, it is routine practices to wash hands prior to eating, after examining a patient and before surgery, in order to remove some potentially harmful transient flora as well as reduce a number of resident flora, which might cause opportunities infections (Saba Riaz et al., 2009)

\section{Conclusion}

The Medicated soaps tested in this work showed varied levels of effectiveness against the test isolates. Hence, Crusader among others that showed antibacterial activity can be used to prevent skin infections and transmission of skin pathogens when used in hand washing. However, prolonged used of these soaps could lead to development of microbial resistance in future.

Table 1. Morphological and Biochemical Characteristics of test bacteria

\begin{tabular}{|c|c|c|c|c|c|c|c|c|c|c|c|c|c|}
\hline 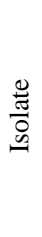 & 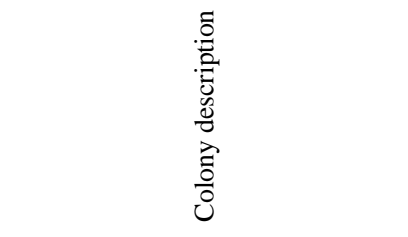 & 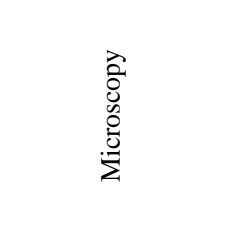 & 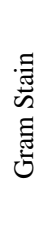 & 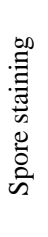 & 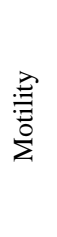 & 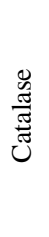 & 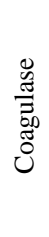 & 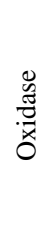 & 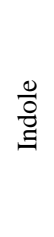 & 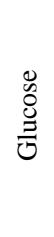 & $\begin{array}{l}\text { U. } \\
\stackrel{0}{0} \\
\stackrel{0}{0} \\
.\end{array}$ & 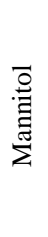 & 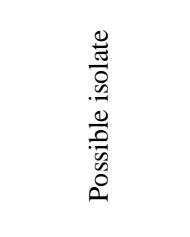 \\
\hline 1. & $\begin{array}{l}\text { Small smooth yellow colonies with } \\
\text { glistering surface }\end{array}$ & $\begin{array}{l}\text { Cocci in grape - } \\
\text { like cluster }\end{array}$ & + & - & + & + & + & - & - & + & + & + & $\begin{array}{c}\text { Staphylococcus } \\
\text { aureus }\end{array}$ \\
\hline 2. & $\begin{array}{l}\text { Raised pinkish colonies on } \\
\text { Mcconkey agar. }\end{array}$ & $\begin{array}{l}\text { Tiny or short rods } \\
\text { in cluster }\end{array}$ & - & - & + & - & + & + & + & + & - & - & Escherichia coli \\
\hline
\end{tabular}


Table 2. Diameter of Zone of Inhibition (mm) on Staphylococcus aureus by soap samples

\begin{tabular}{|c|c|c|c|c|c|c|}
\hline \multicolumn{7}{|c|}{$\mathrm{MEAN} \pm \mathrm{SD}$} \\
\hline $500 \mathrm{mg} / \mathrm{ml}$ & $25.0 \pm 1.41^{\mathrm{a}}$ & $23 \pm 2.83^{\mathrm{a}}$ & $20.0 \pm 1.41^{\mathrm{a}}$ & $18.0 \pm 1.41^{\mathrm{a}}$ & $16.0 \pm 2.83^{\mathrm{a}}$ & $13.0 \pm 2.83^{\mathrm{a}}$ \\
\hline $250 \mathrm{mg} / \mathrm{ml}$ & $21.0 \pm 2.12^{\mathrm{ab}}$ & $19.0 \pm 1.41^{\mathrm{ab}}$ & $17.0 \pm 1.41^{\mathrm{a}}$ & $16.0 \pm 1.41^{\mathrm{ab}}$ & $13.0 \pm 2.83^{\mathrm{a}}$ & $12.0 \pm 1.41^{\mathrm{a}}$ \\
\hline $125 \mathrm{mg} / \mathrm{ml}$ & $18.0 \pm 1.41^{\mathrm{bc}}$ & $16.0 \pm 2.83^{\mathrm{ab}}$ & $15.0 \pm 1.41^{\mathrm{ab}}$ & $16.0 \pm 2.83^{\mathrm{ab}}$ & $10.0 \pm 1.41^{\mathrm{a}}$ & $10.0 \pm 0.71^{\mathrm{a}}$ \\
\hline $62.5 \mathrm{ml} / \mathrm{ml}$ & $14.0 \pm 2.83^{c}$ & $12.0 \pm 2.83^{b}$ & $11.0 \pm 2.83^{b}$ & $10.0 \pm 4.24^{\mathrm{b}}$ & $10.0 \pm 1.41^{\mathrm{a}}$ & $9.0 \pm 2.83^{\mathrm{a}}$ \\
\hline CONCENTRATIONS & TETMOSOL & DETTOL & TCP & CARAT & DELTA & ANTIGAL \\
\hline \multicolumn{7}{|c|}{$\mathrm{MEAN} \pm \mathrm{SD}$} \\
\hline $500 \mathrm{mg} / \mathrm{ml}$ & $20.0 \pm 1.41^{\mathrm{a}}$ & $10.0 \pm 1.41^{\mathrm{a}}$ & $9.0 \pm 1.41^{\mathrm{a}}$ & $6.0 \pm 1.41^{\mathrm{a}}$ & $6.0 \pm 0.71^{\mathrm{a}}$ & $5.0 \pm 2.83^{\mathrm{a}}$ \\
\hline $250 \mathrm{mg} / \mathrm{ml}$ & $170 \pm 2.83^{\mathrm{a}}$ & $8.0 \pm 1.41^{\mathrm{a}}$ & $7.0 \pm 1.41^{\mathrm{a}}$ & $5.0 \pm 0.71^{\mathrm{a}}$ & $5.0 \pm 1.41^{\mathrm{a}}$ & $4.0 \pm 1.41^{\mathrm{ab}}$ \\
\hline $125 \mathrm{mg} / \mathrm{ml}$ & $14.0 \pm 4.24^{\mathrm{a}}$ & $8.0 \pm 4.24^{\mathrm{a}}$ & $5.0 \pm 2.83^{\mathrm{a}}$ & $4.0 \pm 1.41^{\mathrm{a}}$ & $5.0 \pm 1.41^{\mathrm{a}}$ & $4.0 \pm 1.41^{\mathrm{ab}}$ \\
\hline $62.5 \mathrm{ml} / \mathrm{ml}$ & $9.0 \pm 0.00^{\mathrm{a}}$ & $7.0 \pm 1.41^{\mathrm{a}}$ & $5.0 \pm 1.41^{\mathrm{a}}$ & $40 . \pm 0.71^{\mathrm{a}}$ & $4.0 \pm 1.41^{\mathrm{a}}$ & $3.0 \pm 1.41^{\mathrm{b}}$ \\
\hline
\end{tabular}

a,b,c superscript shows level of significance. Similar superscripts means: No significance

Different subscripts=significant difference

Table 3. Diameter of Zone of Inhibition (mm) on Escherichia coli by soap samples

\begin{tabular}{|c|c|c|c|c|c|c|}
\hline \multicolumn{7}{|c|}{$\mathrm{MEAN} \pm \mathrm{SD}$} \\
\hline $500 \mathrm{mg} / \mathrm{ml}$ & $200 \pm 141^{\mathrm{a}}$ & $16.0 \pm 1.41^{\mathrm{a}}$ & $11.5 \pm 0.71^{\mathrm{a}}$ & $13.0 \pm 1.41^{\mathrm{b}}$ & $10.0 \pm 1.41$ & $10.0 \pm 2.83^{a}$ \\
\hline $250 \mathrm{mg} / \mathrm{ml}$ & $17.0 \pm 2.83^{\mathrm{a}}$ & $13.0 \pm 2.82^{\mathrm{ab}}$ & $9.0 \pm 1.41^{\mathrm{ab}}$ & $10.0 \pm 1.41^{\mathrm{ab}}$ & $7.0 \pm 1.41^{\mathrm{ab}}$ & $8.0 \pm 1.41^{\mathrm{a}}$ \\
\hline $125 \mathrm{mg} / \mathrm{ml}$ & $4.0 \pm 4.24^{\mathrm{ab}}$ & $10.0 \pm 2.82^{\mathrm{ab}}$ & $7.0 \pm 1.14$ & $8.0 \pm 1.41^{\mathrm{b}}$ & $5.0 \pm$ & $6.5 \pm 2.12^{\mathrm{a}}$ \\
\hline $62.5 \mathrm{ml} / \mathrm{ml}$ & $9.0 \pm 0.00^{\mathrm{b}}$ & $7.0 \pm 1.41^{\mathrm{b}}$ & $9.0 \pm 1.41^{\mathrm{ab}}$ & $6.0 \pm 1.41$ & $5.0 \pm 1.41^{b}$ & $6.5 \pm 0.71^{\mathrm{a}}$ \\
\hline CONCENTRATIONS & TETMOSOL & DELTOL & TCP & CARAT & DELTA & ANTIGAL \\
\hline \multicolumn{7}{|c|}{$\mathrm{MEAN} \pm \mathrm{SD}$} \\
\hline $500 \mathrm{mg} / \mathrm{ml}$ & $10.0 \pm 2.83^{\mathrm{a}}$ & $7.0 \pm 2.83^{\mathrm{a}}$ & $10.0 \pm 1.41^{\mathrm{a}}$ & $6.0 \pm 1.41^{\mathrm{a}}$ & $6.0 \pm 1.41^{\mathrm{a}}$ & $5.0 \pm 1.41$ \\
\hline $250 \mathrm{mg} / \mathrm{ml}$ & $8.0 \pm 2.83^{\mathrm{a}}$ & $4.0 \pm 1.41^{\mathrm{a}}$ & $9.0 \pm 1.41^{\mathrm{a}}$ & $9.0 \pm 1.41^{\mathrm{a}}$ & $5.0 \pm 1.41^{\mathrm{a}}$ & $4.0 \pm 1.41$ \\
\hline $125 \mathrm{mg} / \mathrm{ml}$ & $7.5 \pm 0.71^{\mathrm{a}}$ & $3.0 \pm 1.41^{\mathrm{a}}$ & $7.0 \pm 2.83^{\mathrm{a}}$ & $7.0 \pm 2.83^{\mathrm{a}}$ & $5.0 \pm 1.41^{\mathrm{a}}$ & $4.0 \pm 1.41^{\mathrm{a}}$ \\
\hline $62.5 \mathrm{ml} / \mathrm{ml}$ & $7.0 \pm 1.41^{\mathrm{a}}$ & $3.0 \pm 1.41^{\mathrm{a}}$ & $6.0 \pm 1.41^{\mathrm{a}}$ & $6.0 \pm 1.41^{\mathrm{a}}$ & $4.0 \pm 1.41^{\mathrm{a}}$ & $4.0 \pm 1.41^{\mathrm{a}}$ \\
\hline
\end{tabular}

a,b,c superscript shows level of significance. Similar superscripts means: No significance

Different subscripts=significant difference.

\section{Recommendation}

Due to the observed medicated soaps effect, it is recommended that irrational and long time usage of these products should be discouraged. It is important that during development of tropical antimicrobial products, a multidimensional approach be adopted. This will ensure that resultant products are designed for specific media of the market and that those needs are met. Ultimately, the product is more likely to have a long, useful, and profitable utilization.

\section{References}

[1] Bauer, A.W, Kirby, W.M, Sherris, J.C and Jurck, M (1966). Antibiotic susceptibility testing by a standard single disc method. American Journal Clinical Pathology. 451: 493-496

[2] Bhargava, H.N and Leonard, P.A (1996). Triclosan, application and safety. American journal of infection control 24: 209-18.

[3] Cheesbrough M (2005). District laboratory practice in tropical countries, part 2. Cambridge University Press, Cambridge. pp159162.

[4] Feroze, K., Elsayed, A and Tarek, T. A (2014) Antimicrobial activity of commercial "antibacterial" handwashes and soaps. Indian Dermatol Online J. 5 (3): 344-346.

[5] Fluit, A.C., Schmits, F. J and Verhoef, J (2001). Frequency and isolation of pathogens from blood stream nosocomial pneumonia, skin and soft tissue, and urinary European. Journal of microbiology infection 20: 188-191.

[6] Friedman, M and Wolf, R (1996). Chemistry of soaps and detergents various types of commercial products and their ingredient. Clinical dermatology 14: 7-13.

[7] Higaki, S., Kitagawa, T., kagoura, M., Morohashi, $\mathrm{M}$ and Yamagishi T (2000).Predominant Staphylococcus aureus isolated from various skin disease. Journal of International Medical Research 28 : 87-190.

[8] Johnson, S.A., Goddard, P.A., Ilife,C.. Timmens, B., Richard., A.H., Robson, G and Handley, P.S (2002). Comparative susceptibility of resident and transient hand bacteria to para- chlorometa-xylenol and triclosan. Journal of Applied Microbiology. 93: 336-344

[9] Kimel, L.S (1996). Hand washing education can decreases illness absenteeism. Journal of School Nursery. 12: 14-18.

[10] Larson, E, McGinley, K., Grove, G.L., Leyden. J.J and Talbot, G.H (1989). Physiologic, microbiologic and seasonal effects of hand washing on the skin of health care personnel. American Journal of Infection control 14: 5-90.

[11] Ndukwe, I.G., Ampitan, J.O., and Isha, Y. (2005) Phytochemical and antimicrobial screening of crude extracts from the root stem bark and leaves Vitellaria paradoxa African Journal of Micro Biology 6 (16): 1905-1909.

[12] Nwambete, K.D and Lyombe, F (2011).Antimicrobial activity of medicated soaps commonly used by Dares Salam residents in Tanzania. Indian Journal of Pharmaceutical sciences 73(1): 92-98.

[13] Osborne, R.C and Grube, J (1982). Hand disinfection in dental practice, Journal of Clinical Preview. Dent 4:11-15.

[14] Poole, K (2002). Mechanisms of bacterial bioade and antibiotic resistance. Journal of Applied Microbiology. 92: 555-564.

[15] Rama Bhat P., Prajna, P.S., Vinita Preethi Menezez and Pavithra Shettuy (2011): Anitmicrobial activities of soaps and detergent. Advances in Biotechnology Research

[16] Richards, M.J, Edwards,J.E., Culver, D.H and Gaynes, R.P (1999). Nosocomial infections in medical intensive care units in the United States. National Nosocomial infections surveillance system. Critical Care Medicine journal 27. 887-892.

[17] Saba Riaz, Adeel Ahmad and Shahida Hasnain. (2009). Antibacterial activity of soaps against daily encountered bacterial. African Journal of Biotechnology 8 (8): 1431-1436.

[18] Selvamohan,, V and Sandhya, T. (2012). Studies on the bactericidal activity of different soaps against bacterial strains. Journal of Microbiology and Biotechnology Research (5): 646650

[19] Whitehouse station (NJ): Merck and Co. Inc., (2008): The Merck Veterinary manual-Tropical antifungal agent. Assessable at, www. Merckvetmanual. Com.

[20] White, D.G and McDermolt, P.F ((2001). Biocides, drug resistance and microbial evolution; Current Opinion in Microbiology; 4: 313-317. 